\title{
MICRODISTRIBUTIONAL VARIABILITY OF LARVAL CADDISFLIES IN MEDITERRANEAN-CLIMATE STREAMS IN NORTHERN CALIFORNIA
}

\author{
Joseph R. Holomuzki ${ }^{1,5}$, Paula C. Furey ${ }^{2}$, Rex L. Lowe ${ }^{3}$, and Mary E. Power ${ }^{4}$
}

\begin{abstract}
Knowing how physical and biogenic habitat characteristics affect microspatial variability of larval caddisflies is important to understanding potential population distributions and local species assemblages. We show that larval caddisfly densities and assemblages vary between study reaches and streams on the Angelo Coast Range Reserve in northern California and that species abundance patterns are associated with specific habitat variables. Dicosmoecus gilvipes and Psychoglypha spp. were most dense in 4th-order reaches of the south fork of the Eel River (SFE) and rare or absent in shallow 2nd- and 1st-order reaches of the Elder and Fox Creek tributaries, respectively. Multidimensional scaling (MDS) suggested D. gilvipes densities were associated with water depth, as microdistributions were restricted to depths $>40 \mathrm{~cm}$. Microdistributions were also associated with Rivularia-dominated algal patches, but it is doubtful grazing $D$. gilvipes tracked these cyanobacteria. Psychoglypha spp. were typically found between roughness elements (stones) in relatively deep waters, and MDS suggested that densities of Psychoglypha spp. were related to current velocity. Lepidostoma sp. was densest in Fox Creek, and densities of this detritivore were associated with benthic organic matter (BOM). Glossosoma spp. densities were similar among streams $\left(\sim 25\right.$ larvae $\left.\cdot \mathrm{m}^{-2}\right)$ and did not configure around any of the habitat variables used in MDS. Neophylax (likely rickeri), Heteroplectron, Ecclisomyia, and Hydatophylax hesperus were uncommon and found only in either Elder or Fox creeks. Our work shows that larval caddisfly assemblages are more diverse in SFE tributaries than in the mainstem and that species traits and microdistributions are related to local-scale habitat variables in these Mediterranean-climate streams.
\end{abstract}

RESUMEN.-Es importante conocer de qué manera las características del hábitat físico y biogénico afectan la variabilidad microespacial de la larva de las frigáneas para comprender la posible distribución local y cómo están compuestos los grupos de especies locales. Demostramos que las densidades y los grupos de las larvas de las frigáneas varían entre los fragmentos del arroyo y entre los arroyos que se encuentran en Angelo Coast Range Reserve en el norte de California y que los patrones de abundancia de las especies se asocian con variables específicas del hábitat. Las especies Dicosmoecus gilvipes y Psychoglypha registraron una mayor densidad en las extensiones del $4^{\circ}$ orden de South Fork del Eel River (SFE) y su densidad disminuyó o se extinguió en las extensiones de menor profundidad del $2^{\circ}$ y del $1^{\circ}$ orden de sus afluentes, los arroyos Elder y Fox respectivamente. El escalamiento multidimensional (EMD) sugirió que la densidad de $D$. gilvipes se asoció con la profundidad del agua, ya que la microdistribución se limitó a profundidades $>40$ $\mathrm{cm}$. La microdistribución también se asoció a zonas con predominancia de algas de Rivularia, pero no es seguro que $D$. gilvipes haya rastreado estas cianobacterias. La especie Psychoglypha se encontró típicamente entre elementos ásperos (piedras) en aguas relativamente profundas y el EMD sugirió que su densidad se relacionaba con la velocidad de la corriente. La especie Lepidostoma fue la más densa en el arroyo Fox y la densidad de este detritívoro se asoció con la materia orgánica bentónica $(B O M)$. La densidad de la especie Glossosoma fue similar entre los arroyos $\left(\sim 25\right.$ larvas $\left.\cdot \mathrm{m}^{-2}\right)$ y no determinó ninguna de las variables del hábitat utilizadas en el EMD. Neophylax (probablemente rickeri), Heteroplectron, Ecclisomyia y Hydatophylax hesperus fueron poco comunes y sólo se encontraron en el arroyo Elder o en el Fox. Nuestra investigación demuestra que los grupos de larvas de las frigáneas son más diversos en los afluentes del SFE que en la corriente principal, y que las características y la microdistribución de las especies se relacionan con variables del hábitat a escala local en estos arroyos de clima mediterráneo.

Physical and biogenic habitat characteristics interact to affect microdistributional variability and phenotypic composition of larval stream caddisfly assemblages. For example, species residing in slow-flowing areas where fine sediments (sand grains) or benthic organic matter (BOM: leaves, twigs, detritus) accumulate often build cases from these materials (Eggert and Wallace 2003) in high-flow intolerant shapes (e.g., Heteroplectron-Anderson et al. 1984). In contrast, species residing in fast-flowing areas with coarse, stable substrates

\footnotetext{
${ }^{1}$ Department of Evolution, Ecology, and Organismal Biology, Ohio State University, 1760 University Drive, Mansfield, OH 44906.

${ }^{2}$ Department of Biology, St. Catherine University, 2004 Randolph Avenue, St. Paul, MN 55105.

${ }^{3}$ Department of Biological Sciences, Bowling Green State University, Bowling Green, OH 43403.

${ }^{4}$ Department of Integrative Biology, University of California, Berkeley, 4184 Valley Life Sciences Building, Berkeley, CA 94720.

${ }^{5}$ Present address: U.S. Geological Survey, Water Resources, 345 Middlefield Rd., Menlo Park, CA 94025. E-mail: jholomuzki@usgs.gov
} 
(logs, boulders) often build cases with heavier materials (e.g., fine gravel) in hydraulically smooth shapes (e.g., glossosomatids-Patrick 1988) or have special substrate-adhering mechanisms (e.g., tethering silk lines [Pycnocentrodes-Holomuzki and Biggs 2000]; case lateral extensions [Dicosmoecus 1st-4th instarsLimm and Power 2011]). Moreover, larvae that feed by shredding detrital matter $(>2 \mathrm{~mm}$ diameter) often inhabit BOM patches (e.g., limnephilids-Cummins et al. 1989), whereas larvae that feed by filtering fine, detrital particles ( $\leq 2 \mathrm{~mm}$ dia.) carried in the current inhabit fast flows and spin food-capturing nets (e.g., hydropsychids-Fairchild and Holomuzki 2002). Larval feeding mode can even influence ecosystem processes. Sometimes detritivores can drive decomposition processes (Whiles et al. 1993, Ruesink and Srivastava 2001), and herbivores that scrape periphyton or clip filamentous algae can limit algal biomass and production (Feminella and Hawkins 1995, McNeely et al. 2007). So connecting microhabitat structure, microdistributions, and species traits of larval caddiflies can potentially produce fundamental insights into local population dynamics, trophodynamics, and stream ecosystem function.

We studied how microhabitat heterogeneity was linked to reach-scale spatial variability of caddisfly larvae in the south fork of the Eel River (SFE) and 2 of its tributaries on the Angelo Coast Range Reserve $\left(39^{\circ} 43^{\prime} 45^{\prime \prime} \mathrm{N}\right.$, $123^{\circ} 38^{\prime} 40^{\prime \prime} \mathrm{W}$ ) in Mendocino County, northern California. Dicosmoecus gilvipes (Hagen), a large-bodied (5th instars: $25-30 \mathrm{~mm}$ in length), case-building (1st-4th instars: mostly plant matter; 5th instar: fine gravel) limnephilid, and Cladophora glomerata (L.) (Kütz.), a filamentous green alga, are key grazers and primary producers, respectively, in mainstem channels of the Eel drainage network (Power et al. 2009). However, under the region's Mediterranean climate, both caddisfly and algal abundance is strongly influenced by winter-scour intensity. In mainstem channels, large Cladophora blooms occur in summer if winter spates are intense enough to mobilize much of the river bed and eliminate grazing Dicosmoecus. Summer blooms are checked by Dicosmoecus if winter floods are mild (Power et al. 2008), and epilithic, nitrogen-fixing Epithemia diatoms and Rivularia cyanobacteria codominate with Cladophora (Power et al. 2009).
Dicosmoecus also eats an array of diatoms (Jacoby 1987), but it is unknown if their microdistributions are related to algal type. Algal proliferations are spatially heterogeneous and dynamic over the Eel drainage basin (Power et al. 2009), and algal spatial variability could predict grazer spatial variability, if grazers are tracking specific resources. Glossosoma penitum (Banks), G. califica (Denning), and Neophylax rickeri (Milne) (Limnephilidae) are also relatively common algivores in the SFE drainage, and Psychoglypha spp. (Limnephilidae) is a common detritivore (Teague et al. 1985, McNeely et al. 2006, McNeely and Power 2007). However, it is unknown how larval caddisfly occurrence changes from mainstem channels to lower-order tributaries that experience milder winter floods. In this paper, we address the following questions: (1) How do species' traits and microdistributions relate to substrate attributes, microhydraulics, and potential food supply (algae or BOM) in a summer preceded by mild-winter floods? (2) How do larval caddisfly assemblages differ between the mainstem and its smaller-order tributaries?

\section{Methods \\ Study Sites}

Larval caddisfly counts and microdistribution determinations were done in 4th-order reaches of the SFE (catchment area $148 \mathrm{~km}^{2}$ ) and in 2nd- and 1st-order reaches of its Elder Creek (catchment $17 \mathrm{~km}^{2}$ ) and Fox Creek (catchment $2 \mathrm{~km}^{2}$ ) tributaries, respectively (Fig. 1). Old-growth mixed hardwood-conifer forest dominated by Douglas-fir (Pseudotsuga menziesii) surrounded study reaches in these coarse-bedded streams (McNeely and Power 2007). Litter abundance was relatively high, even in summer, as evergreen and deciduous trees lose their leaves during the dry season (McNeely et al. 2007). Algal standing crops were low in both tributaries (Elder: 299 [SE $71] \times 10^{3}$ cells $\cdot \mathrm{cm}^{-2}$; Fox: $79\left[\mathrm{SE} \mathrm{21]} \times 10^{3}\right.$ cells $\left.\cdot \mathrm{cm}^{-2}\right)$ relative to SFE $(1254$ [SE 278] $\times$ $10^{3}$ cells $\cdot \mathrm{cm}^{-2}$; J.R. Welter and P.C. Furey unpublished data). Midday temperatures in July are cooler in Elder and Fox creeks (13-15 $\left.{ }^{\circ} \mathrm{C}\right)$ than in SFE $\left(14-18^{\circ} \mathrm{C}\right)$.

\section{Larval Caddisfly Sampling}

Larvae were counted in a $0.5 \times 0.5-\mathrm{m}$ quadrat made of PVC pipe. The quadrat was 


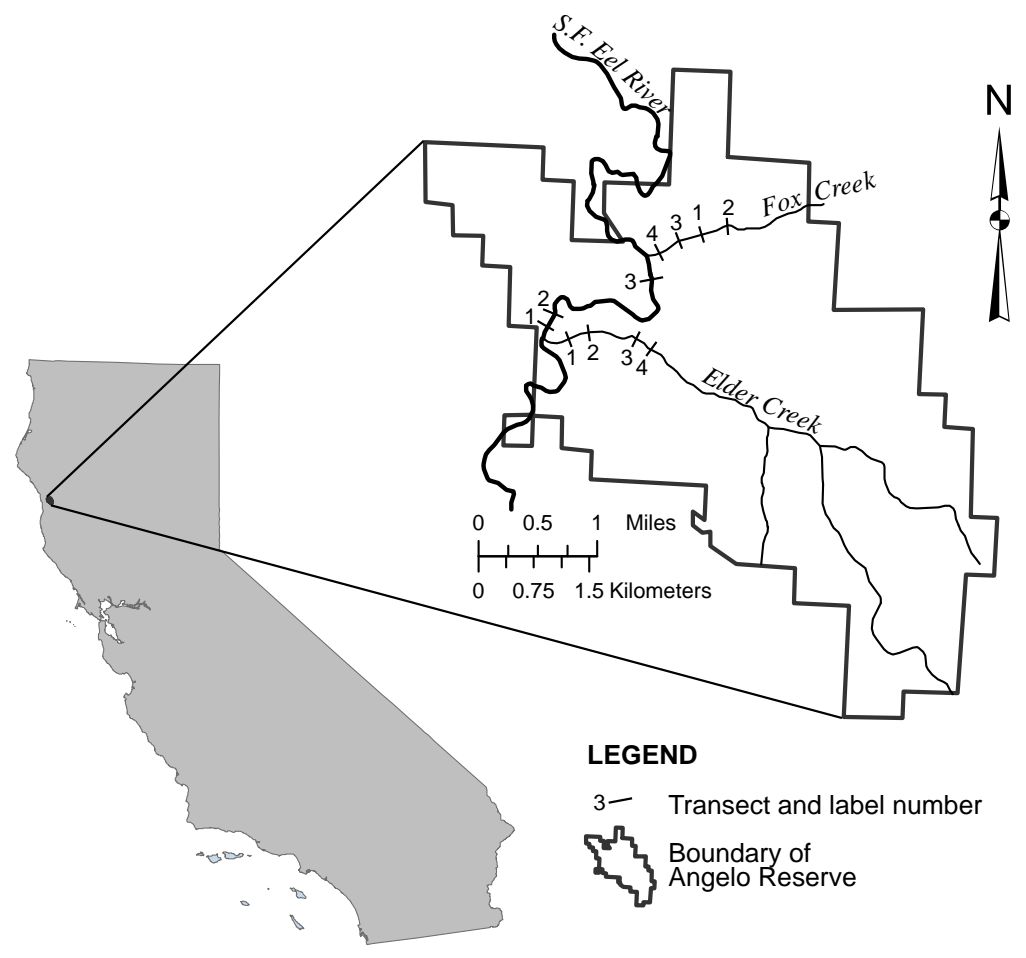

Fig. 1. Transects along sample reaches in the south fork of the Eel River, Elder Creek, and Fox Creek in the Angelo Range Coast Reserve in northern California.

placed at 1- or 2-m intervals along a transect stretching across, and perpendicular to, the channel. Two transects were sampled in SFE on 18 July and one on 20 July; 4 transects were sampled in Elder Creek on 19 July; and 4 transects were sampled on Fox Creek on 20 July 2011. Number of quadrat samples taken from each transect varied depending on reach width (SFE: 10.5-18.0 m; Elder: 5.5-6.5 m; Fox: 2.5-3.5 m). Specifically, 8, 5, and 7 quadrat samples were taken along transects (reaches) 1,2 , and 3 at SFE, respectively; $5,6,4$, and 5 samples were taken on transects $1,2,3$, and 4 at Elder Creek, respectively; and, 3 samples were taken on each transect at Fox Creek. Transect location was based largely on accessibility and wadeability and often spanned a variety of substrate types and sizes. Transects were spaced $\sim 80-200 \mathrm{~m}$ apart within a stream (Fig. 1).

Caddisflies of each species or genus visible on upper surfaces or sides of substrates in quadrats were counted between $\sim 09: 30$ and 16:30; stones were not overturned for counts. A view box was used in deeper areas to facilitate detection of caddisflies. Caddisflies were collected and preserved in $80 \%$ ethanol only if field identifications could not be made. Counts of each species or genus in quadrats were averaged over the reach and expressed as larvae $\cdot \mathrm{m}^{-2}$.

\section{Microhabitat Characterization}

Immediately following the counts, percent composition of inorganic substrata was visually estimated in each quadrat. Substrata were distinguished by size following the Wentworth Scale (Gordon et al. 1992) and classed as bedrock, boulders, cobbles, pebbles, gravel, and sand/silt. Percent BOM (leaves, twigs, and coarse detritus [>2 mm diameter]) cover atop inorganic substrata in quadrats was also estimated visually (Acuña et al. 2007). Current velocities were measured at each sampling quadrat using a Marsh McBirney ${ }^{\circledR}$ flowmeter placed $2 \mathrm{~cm}$ from the bottom. A mean was calculated for each variable to characterize microhabitat conditions along each reach.

A cobble (b axis: $\sim 64-256 \mathrm{~mm}$ ) was collected near or at the midpoint of each sample 
quadrat to determine the dominant alga in the epilithon. The upper rock surface was scraped with a razor blade and rinsed with distilled water over a plastic tray. Algae were poured into a Whirl-pak ${ }^{\circledR}$ bag, taken to the lab for identification within $\sim 3 \mathrm{~h}$ of collection, and viewed at 400X for $\sim 15-20$ min to determine the dominant taxon. Taxa comprising $\geq 50 \%$ of the biomass of a sample were considered dominant. Algae were identified to genus using Krammer and Lange-Bertalot (1986, 1988, 1991a, 1991b) and Patrick and Reimer (1966, 1975) as primary references.

\section{Statistical Analyses}

One-way ANOVAs were used to determine whether caddisfly densities, water depth, boulder abundance, and BOM cover differed among streams. Significant stream effects were followed by Bonferroni pairwise comparisons $(\alpha=0.05)$. To meet the assumptions of ANOVA, caddisfly densities were $\log _{10}[\mathrm{x}+1]$ transformed, and boulder and BOM cover were arcsine-transformed. Multidimensional scaling (MDS; SYSTAT, version 13) was used to associate microhabitat variables with caddisfly densities. Quadrat samples were averaged along each transect for each variable, so transect was the unit of replication in analyses. $G$ tests of independence $(2 \times 2$ tables; Sokal and Rohlf 1995), adjusted by Williams's correction, determined whether the presence of a dominant alga was associated with presence of a common grazing caddisfly (i.e., Dicosmoecus, Glossosoma).

\section{RESULTS}

The 4 most common caddisflies found were Dicosmoecus gilvipes, Psychoglypha spp., Lepidostoma sp., and Glossosoma penitum. Dicosmoecus and Psychoglypha (bella and leechi) densities differed among study streams (ANOVA; Dicosmoecus: $F_{2.8}=5.198, P=$ 0.036; Psychoglypha: $\left.F_{2,8}=6.040, P=0.025\right)$. Both caddisflies were most dense in the SFE, rare in Elder Creek, and absent in Fox Creek (Table 1). Coincidently, water depths varied among streams $\left(F_{28}=4.441, P=0.05\right)$, with Fox Creek being the shallowest and SFE the deepest (Table 1; Bonferroni comparison: SFE $\neq$ Fox Cr., $P<0.05)$. Indeed, MDS suggested that $D$. gilvipes densites were associated with water depth (Fig. 2), as microdistributions were restricted to depths $>40 \mathrm{~cm}$ (Fig. 3A). Psychoglypha spp. appeared to be associated with current velocity (Fig. 2) and were typically found between, or on downstream sides of, large stones. Only 5th instars were observed for both taxa.

In contrast, Lepidostoma sp. was present in all streams. However, Lepidostoma sp. was denser in Fox Creek than in SFE and Elder (ANOVA: $F_{2,8}=6.040, P=0.025$; Bonferroni comparisons: both $P \leq 0.05$; Table 1). Lepidostoma sp. microdistributions appeared closely associated with BOM (Fig. 2), and BOM cover did not differ among streams $\left(F_{2,8}=2.012, P\right.$ $=0.196$; Table 1). Glossosoma spp. was present and equally dense in all 3 streams $\left(F_{2,8}=\right.$ 3.091, $P=0.101$; Table 1). Neither water depth, current speed, boulder cover, nor BOM cover was associated with Glossosoma spp. density (Fig. 2).

Rarely found were Neophylax, Heteroplectron, Ecclisomyia, and Hydatophylax hesperus (Banks). None of these caddisflies were found at our SFE sites. Ecclisomyia was found only in Elder Creek $\left(<1\right.$ larva $\left.\cdot \mathrm{m}^{-2}\right)$ and H. hesperus only in Fox Creek $\left(<2\right.$ larva $\left.\cdot \mathrm{m}^{-2}\right)$. Neophylax was in both creeks (Elder: $2 \pm 1$ larva $\mathrm{m}^{-2}$; Fox: $3 \pm 2$ larva $\cdot \mathrm{m}^{-2}$ ).

Rankings of the predominant algae in the SFE were Epithemia (typically E. turgida [Ehrenb. Kütz.]) $>$ Rivularia $>$ Stigeoclonium (Table 1). However, Rivularia was dominant only in deeper waters (range 35-83 cm, Fig. $3 \mathrm{~B}$ ), and D. gilvipes presence was associated with Rivularia presence in SFE $\left(G_{\mathrm{adj}}=6.359\right.$, $\mathrm{df}=1, P<0.025)$. Stigeoclonium and Epithemia were codominant at transect 3 , the only sample site in SFE where Glossosoma spp. was relatively abundant (Table 1). However, Glossosoma spp. presence was not associated with either Stigeoclonium or Epithemia presence at the site (both algae: $G_{\text {adj }}=0.059$, $\mathrm{df}=1, P>0.75)$. The dominant algae in Elder Creek were the cyanophytes Tolypothrix and Nostoc (Table 1), which together comprised $\sim 80 \%$ of the algal assemblage. In contrast, the diatom Cocconeis (typically C. placentula Ehrenb.) was by far $(>80 \%)$ the dominant alga in Fox Creek (Table 1). These very different assemblages in Elder and Fox Creeks, coupled with similar densities of Glossosoma, the only abundant grazer in these 2 streams, suggest that algal type and dominance played little role in affecting densities of this caddisfly. 


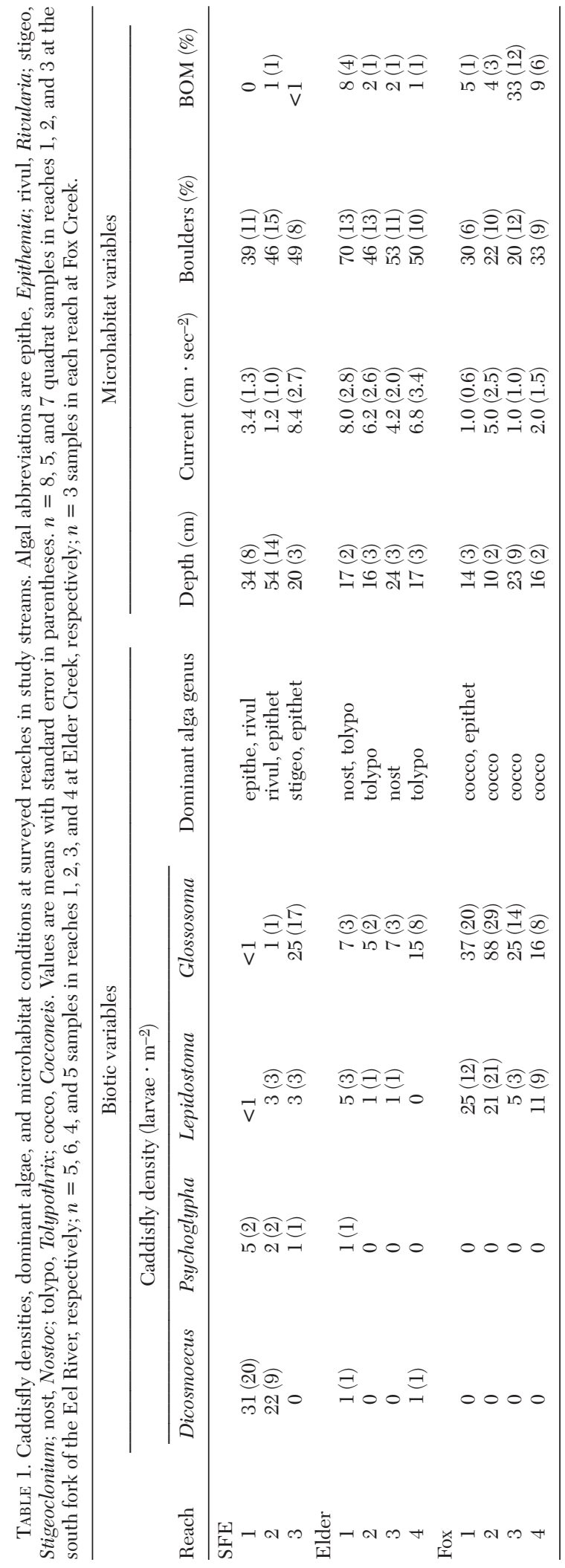




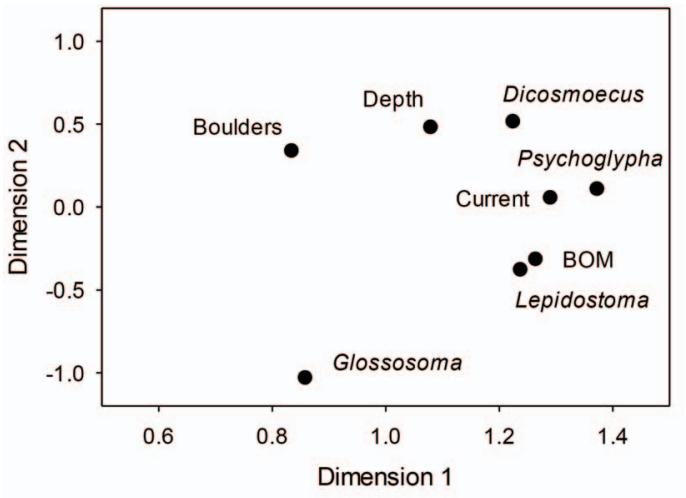

Fig. 2. MDS ordination of Dicosmoecus, Psychoglypha, Lepidostoma, and Glossosoma densities with habitat variables (stress $=0.026, \mathrm{RSQ}=0.914)$.

\section{Discussion}

Dicosmoecus gilvipes densities varied among streams and among reaches within streams. The species was most abundant in the 2 deeper reaches of SFE and absent to rare in shallow Elder and Fox creeks and in the shallowest SFE reach. Dicosmoecus densities were associated with water depth and Rivularia, which was frequently dominant in deep waters in SFE. We doubt that Dicosmoecus tracks Rivularia-dominated algal patches, given that this cyanobacteria produces cyanotoxic microcystins (Aboal et al. 2005), making it a poor food item. More likely, Dicosmoecus indirectly affects Rivularia microdistributions by grazing Cladophora and other epilithic algae, like diatoms. Grazers can facilitate the establishment of other algae, like Rivularia, by preventing substrate monopolization by filamentous green algae (Benedetti-Cecchi 2000). Further, we suspect that Dicosmoecus microdistributions, which were limited to depths $>40 \mathrm{~cm}$ in SFE, are affected by predation risk. Teague et al. (1985) suggested that sizeselective predation by American dippers (Cinclus mexicanus) restricted larger species of caddisflies like Dicosmoecus to deep habitats. Dippers ordinarily dive to depths of $\sim 15$ to 50 cm (Murrish 1970) and apparently selectively feed on relatively large, case-bearing caddisflies (Thut 1970). In contrast, predaceous fish, like steelhead trout (Oncorhynchus mykiss), that reside in deeper, slower waters in SFE have difficulty eating large, armored 5th-instar Dicosmoecus (Power et al. 2008), like those

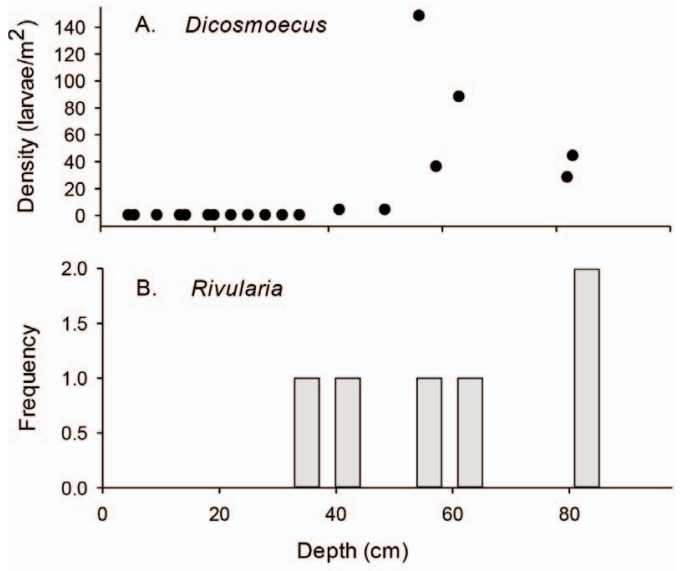

Fig. 3. (A) Quadrat samples along the 3 transects in the south fork of the Eel River $(n=20)$ showing the relationship between water depth and Dicosmoecus gilvipes densities. (B) Depths at which the cyanophyte Rivularia was the dominant alga on stones in quadrats.

encountered in our study. Dippers are common along riparian areas of our study streams, and empty Dicosmoecus cases, along with dipper scat, were found on rocks protruding above the water in our shallowest study reach in SFE (MEP and JRH, personal observation). Whether water depth mediates dipper predation on Dicosmoecus warrants further attention, particularly considering that Discosmoecus can significantly impact local periphyton standing crops (McAuliffe 1984) and production (Lamberti and Resh 1983).

MDS results indicated that Psychoglypha spp. presence was associated with current speed. Erman (1984) found Psychoglypha spp. feeding on plant matter mainly along shallow, slow-flowing stream margins in the Sierra Nevada of California. Psychoglypha are largebodied ( $20 \mathrm{~mm}$ long) and construct a case of plant litter and leaves (Wiggins 1977), which could increase form drag. Occupying slowflowing stream margins or spaces between bed elements with slower flows or stable eddies (Davis and Barmuta 1989, Harrison and Keller 2007) could provide a refugium from hydraulic stress. However, such space use, coupled with large size, could make Psychoglypha spp. vulnerable to predators like dippers. However, we did not find empty Psychoglypha spp. cases on rocks frequented by dippers (MEP and JRH, personal observation), although this observation could, in part, be a result of the 
overall rarity of Psychoglypha spp. in our study streams.

Lepidostoma sp. was densest in our shallowest study stream (Fox Creek). Late Lepidostoma instars ( $8 \mathrm{~mm}$ length; Clifford 1991), like those we found, occur along shallow stream margins or in slow-flowing areas (pools, backwaters), where they consume mainly decaying plant matter (Erman 1984, Leland et al. 1986, Richardson 2001). MDS showed that densities were associated with BOM cover, which suggests that these caddisflies might be tracking food resources or plant detritus for casebuilding materials. The physical complexity of BOM patches might also serve as a refuge from predators (Lancaster et al. 1988).

Glossosoma spp. densities were similar among streams, and none of the environmental variables that we measured were associated with their densities. Densities were $\leq 25$ larva $\cdot \mathrm{m}^{-2}$, except in Fox Creek, where densities averaged $\sim 45$ larva $\cdot \mathrm{m}^{-2}$. In contrast, Teague et al. (1985) reported $\sim 130$ G. penitum larva $\cdot \mathrm{m}^{-2}$ in Fox Creek, and McNeely and Power (2007) found Glossosoma spp. densities approaching 1000 larvae $\cdot \mathrm{m}^{-2}$ in some streams in the SFE drainage during midsummer (July). This variation, in part, is related to stream drainage area. McNeely and Power (2007) reported that G. penitum was most common in small streams with drainage areas between $\sim 2$ and $3 \mathrm{~km}^{2}$, whereas G. califica was common in large streams with drainage areas $>10 \mathrm{~km}^{2}$. They also suggested that low predation pressure might account for the high numbers of Glossosoma in small streams, despite their low productivity and algal biomass. Annual variation in predation pressure and algal productivity could explain density differences between studies. Moreover, we did not count larvae on rock undersides, which probably also contributed to the relatively low densities observed in our study. However, our results do suggest that Glossosoma spp. are not tracking a particular algal food source.

Heteroplectron, Ecclisomyia, and Hydatophylax hesperus were uncommon and found only in either Elder Creek or Fox Creek. These detritivores appear to prefer smallorder streams with dense canopies and high allochthonous inputs (Erman 1984, Beche 2005). Further, we found Neophylax (likely rickeri) in both Elder and Fox Creeks, where densities never exceeded 3 larva $\cdot \mathrm{m}^{-2}$. McNeely and Power (2007) similarly reported that $N$. rickeri was relatively abundant only in small streams in the SFE drainage, where densities peaked $\left(\sim 80\right.$ larva $\left.\cdot \mathrm{m}^{-2}\right)$ in June. Neophylax rickeri life histories (e.g., instar and adult emergence phenology) are highly variable between stream types even over small spatial scales (Mendez and Resh 2008), which might partly explain the low densities of $N$. rickeri we observed in Elder and Fox creeks and its absence in SFE study reaches. These low densities prevented us from ascribing microhabitat associations to Neophylax. However, Teague et al. (1985) found larvae to prefer large rocks, which might present a larger grazing patch than small rocks.

We show that caddisfly densities and assemblages varied between study reaches and streams and that habitat variables associated with microdistributions varied with species. Other studies have similarly shown that hydrological and food-source variability associated with stream size can generate assemblage and species richness differences between streams (Wiberg-Larsen et al. 2000, Meyer et al. 2007) and that local-scale habitat variables (e.g., substrate composition, food type, flow patterns) can strongly relate to caddisfly assemblage structure (Feminella and Resh 1991, Urbani et al. 2005, Gombeer et al. 2011). The preliminary findings reported here, coupled with information from sampling efforts in similar streams over broader time frames, should enable us to better understand how changing reach characteristics might generate predictable patterns in local caddisfly assemblages in Mediterranean-climate streams. Given their functional traits and diversity, small-scale differences in caddisfly abundance patterns could have important effects on large-scale processes, like the flow of algal and detrital carbon and energy through lotic food webs (McNeely and Power 2007).

\section{ACKNOWLEDGMENTS}

We thank Mike Limm for sharing his knowledge of the caddisflies of the Angelo Coast Range Reserve, Jo Ann Gronberg for drawing Fig. 1, and 2 anonymous reviewers and Dave Lightfoot for improving the manuscript. Paula Furey was partly supported by an NSF grant (NSF-DEB 0950016) awarded to Jill Welter of St. Catherine University. 


\section{Literature Cited}

Aboal, M., M. Ángeles Puig, and A.D. Asencio. 2005. Production of microcystins in calcareous Mediterranean streams: the Alharabe River, Segura River basin in south-east Spain. Journal of Applied Phycology 17:231-243.

Acuña, V., A. Giorgi, I. Muñoz, F. Sabater, and S. SABATER. 2007. Meterological and riparian influences on organic matter dynamics in a forested Mediterranean stream. Journal of the North American Benthological Society 26:54-69.

Anderson, N.H., R.J. Steedman, and T. Dudley. 1984. Patterns of exploitation by stream invertebrates of wood debris. Verhandlungen des Internationalen Verein Limnologie 22:1847-1852.

BECHE, L.A. 2005. Long-term variability, disturbance, and biological traits of aquatic invertebrates in Mediterranean-climate streams. Doctoral dissertation, University of California, Berkeley, CA.

Benedetti-Cecchi, L. 2000. Predicting direct and indirect interactions during succession in a mid-littoral rocky shore assemblage. Ecological Monographs 70: 45-72.

Clifford, H.F. 1991. The aquatic insects of Alberta. University of Alberta Press, Alberta, Canada.

Cummins, K.W., M.A. Wilzbach, D.M. Gates, J.B. Perry, AND W.B. TALIAFERRo. 1989. Shredders and riparian vegetation. BioScience 39:24-30.

Davis, J.A., AND L.A. BarmutA. 1989. An ecologically useful classification of mean and near-bed flows in streams and rivers. Freshwater Biology 21:271-282.

Eggert, S.L., and J.B. Wallace. 2003. Reduced detrital resources limit Pycnopsyche gentilis (Trichoptera: Limnephilidae) production and growth. Journal of the North American Benthological Society 22: 388-400.

Erman, N.A. 1984. The use of riparian systems by aquatic insects. In: R.E. Warner and K.M. Hendrix, editors, California riparian systems: ecology, conservation, and productive management. University of California Press, Berkeley, CA.

FAIRChILD, M.P., AND J.R. HolOMUZKI. 2002. Spatial variability and assemblage structure of stream hydropsychid caddisflies. Journal of the North American Benthological Society 21:576-588.

FeminelLa, J.W., and C.P. HaWkins. 1995. Interactions between stream herbivores and periphyton: a quantitative analysis of past experiments. Journal of the North American Benthological Society 14:465-509.

Feminella, J.W., And V.H. Resh. 1991. Herbivorous caddisflies, macroalgae, and epilithic microalgae: dynamic interactions in a stream grazing system. Oecologia (Berlin) 87:247-256.

Gombeer, S.C., D. Knapen, and L. Bervoets. 2011. The influence of different spatial-scale variables on caddisfly assemblages in Flemish lowland streams. Ecological Entomology 36:355-368.

Gordon, N.D., T.A. McMahon, and B.L. Finlayson. 1992. Stream hydrology: an introduction for ecologists. John Wiley \& Sons, West Sussex, England.

HARRISON, L.R., AND E.A. KeLLER. 2007. Modeling forced pool-riffle hydraulics in a boulder-bed stream, southern California. Geomorphology 83:232-248.

Holomuzki, J.R., AND B.J.F. BigGs. 2000. Taxon-specific responses to high-flow disturbance in streams: implications for population persistence. Journal of the North American Benthological Society 19: 670-679.

JACOBY, J.M. 1987. Alterations in periphyton characteristics due to grazing in a Cascade foothill stream. Freshwater Biology 18:495-508.

Krammer, K., and H. Lange-Bertalot. 1986. Bacillariophyceae. 1. Teil: Naviculaceae. In: H. Ettl, J. Gerloff, H. Heynig, and D. Mollenhauer, editors, Süßwasserflora von Mitteleuropa, Band 2/1. Gustav Fischer Verlag, Stuttgart/New York. 876 pp.

1988. Bacillariophyceae. 2. Teil: Bacillariaceae, Epithemiaceae, Surirellaceae. In: H. Ettl, J. Gerloff, H. Heynig, and D. Mollenhauer, editors, Süßwasserflora von Mitteleuropa, Band 2/2. VEB Gustav Fischer Verlag, Jena, Germany. 610 pp.

. 1991a. Bacillariophyceae. 3. Teil: Centrales, Fragilariaceae, Eunotiaceae. In: H. Ettl, J. Gerloff, H. Heynig, and D. Mollenhauer, editors, Süßwasserflora von Mitteleuropa, Band 2/3. Gustav Fischer Verlag, Stuttgart, Jena, Germany. 598 pp.

1991b. Bacillariophyceae. 4. Teil: Achnanthaceae, Kritische Ergänzungen zu Navicula (Lineolatae) und Gomphonema, Gesamtliteraturverzeichnis Teil 1-4. In: H. Ettl, G. Gärtner, J. Gerloff, H. Heynig, and D. Mollenhauer, editors, Süßwasserflora von Mitteleuropa, Band 2/4. Gustav Fischer Verlag, Stuttgart/Jena, Germany. 437 pp.

Lamberti, G.A., AND V.H. RESh. 1983. Stream periphyton and insect herbivores: an experimental study of grazing by a caddisfly population. Ecology 64: 1124-1135.

Lancaster, J.A., A.G. Hildrew, and C.R. Townsend. 1988. Competition for space by predators in streams: field experiments on a net-spinning caddisfly. Freshwater Biology 20:185-193.

Leland, H.V., S.V. Fend, J.L. Carter, and A.D. Mahood. 1986. Composition and abundance of periphyton and aquatic insects in a Sierra Nevada, California stream. Great Basin Naturalist 46:595-611.

Limm, M.P., AND M.E. Power. 2011. The caddisfly Dicosmoecus gilvipes: making a case for a functional role. Journal of the North American Benthological Society 30:485-492

McAuliffe, J.R. 1984. Competition for space, disturbance, and the structure of a benthic stream community. Ecology 65:894-908.

McNeely, C., S.M. Clinton, and J.M. Erbe. 2006. Landscape variation in $\mathrm{C}$ sources of scraping primary consumers in streams. North American Benthological Society 25:787-799.

McNeely, C., J.C. Finlay, and M.E. Power. 2007. Grazer traits, competition, and carbon sources to a headwater-stream food web. Ecology 88:391-401.

MCNeEly, C., AND M.E. Power. 2007. Spatial variation in caddisfly grazing regimes within a northern California watershed. Ecology 88:2609-2619.

MendeZ, P.K., AND V.H. RESH. 2008. Life history of Neophylax rickeri (Trichoptera: Uenoidae) in two northern California streams. Annals of the Entomological Society of America 101:573-584.

Meyer, J.L., D.L. Strayer, J.B. Wallace, S.L. Eggert, G.S. Helfman, and N.E. LeOnard. 2007. The contribution of headwater streams to biodiversity in river networks. Journal of the American Water Resources Association 43:86-103. 
Murrish, D.E. 1970. Responses to diving in the dipper Cinclus mexicanus. Comparative Biochemical Physiology 34:853-858.

PATRICK, R. 1988. Importance of diversity in the functioning and structure of riverine communities. Limnology and Oceanography 33:1304-1307.

Patrick, R., AND C.W. Reimer. 1966. The diatoms of the United States, exclusive of Alaska and Hawaii, Volume 1. Fragilariaceae, Eunotiaceae, Achnanthaceae, Naviculaceae. Academy of Natural Sciences of Philadelphia Monograph No. 13. 688 pp.

. 1975. The diatoms of the United States, exclusive of Alaska and Hawaii. Volume 2, Part 1. Entomoneidaceae, Cymbellaceae, Gomphonemaceae, Epithemaceae. Academy of Natural Sciences of Philadelphia Monograph No. 13. 213 pp.

Power, M., R. Lowe, P. Furey, J. Welter, M. Limm, J. Finlay, C. Bode, S. Chang, M. GoOdrich, and J. SCULLEY. 2009. Algal mats and insect emergence in rivers under Mediterranean climates: towards photogrammetric surveillance. Freshwater Biology 54: 2101-2115.

Power, M.E., M.S. Parker, and W.E. Dietrich. 2008. Seasonal reassembly of a river food web: floods, droughts, and impacts of fish. Ecological Monographs 78:263-282.

RichaRDSON, J.S. 2001. Life cycle phenology of common detritivores from a template rainforest stream. Hydrobiologia 455:87-95.

Ruesink, J.L., and D.S. SRIVastava. 2001. Numerical and per capita responses to species loss: mechanisms maintaining ecosystem function in a community of stream insect detritivores. Oikos 93:221-234.

SOKaL, R.R., AND FJ. Rohlf. 1995. Biometry. 3rd edition. W.H. Freeman, New York, NY.

Teague, S.A., A.W. Knight, and B.N. Teague. 1985. Stream microhabitat selectivity, resource partitioning, and niche shifts in grazing caddisfly larvae. Hydrobiologia 128:3-12.

Thut, R.N. 1970. Feeding habits of the dipper in southwestern Washington. Condor 72:234-235.

Urbani, G., M.J. Toman, and C. KRUŠnik. 2005. Microhabitat type selection of caddisfly larvae (Trichoptera) in a shallow lowland stream. Hydrobiologia 541:1-12.

Whiles, M.R., J.B. Wallace, and K. Chung. 1993. The influence of Lepidostoma (Trichoptera: Lepidostomatidae) on recovery of leaf-litter processing in disturbed headwater streams. American Midland Naturalist 130:356-363.

Wiberg-Larsen, P., K.P. Brodersen, S. Birkholm, P.N. Gron, And J. Skriver. 2000. Species richness and assemblage structure of Trichoptera in Danish streams. Freshwater Biology 43:633-647.

Wiggins, G.B. 1977. Larvae of the North American caddisfly genera. University of Toronto Press, Toronto, Canada.

Received 3 May 2012 Accepted 2 May 2013 